\title{
Monitoring of Groundwater Quality With Cokriging of Geochemical and Geoelectrical Measurements
}

doi:10.2478/mape-2021-0009

Date of submission to the Editor: 04/2021

Date of acceptance by the Editor: 06/2021

MAPE 2021, volume 4, issue 1, pp. 97-106

Jarosław Zawadzki

ORCID ID: 0000-0003-2842-0018

Warsaw University of Technology, Poland

Piotr Fabijańczyk

ORCID ID: 0000-0002-0769-2324

Warsaw University of Technology, Poland

\section{Wiktor Treichel}

ORCID ID: 0000-0001-7061-1243

Warsaw University of Technology, Poland

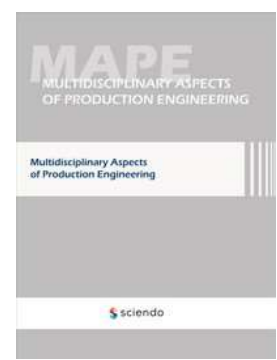

\section{INTRODUCTION}

Żelazny Most dump was constructed in 1977 to collect flotation tailings from nearby copper ores. Initially it was placed in the natural depression bordered from north and south by hill ranges, as unsealed dam. With run of time volume of stored tailings was increasing and it was necessary to raise embankments, especially at eastern and western sides of the dump, unsealed by hill ranges. At present dam has a circumference of $15 \mathrm{~km}$ and a height up to $60 \mathrm{~m}$ (Skau et al., 2013). It is projected that the total volume of tailings stored in Żelazny Most dump will reach 1000 millions $\mathrm{m}^{3}$ in 2042 (Jamiolkowski, 2014).

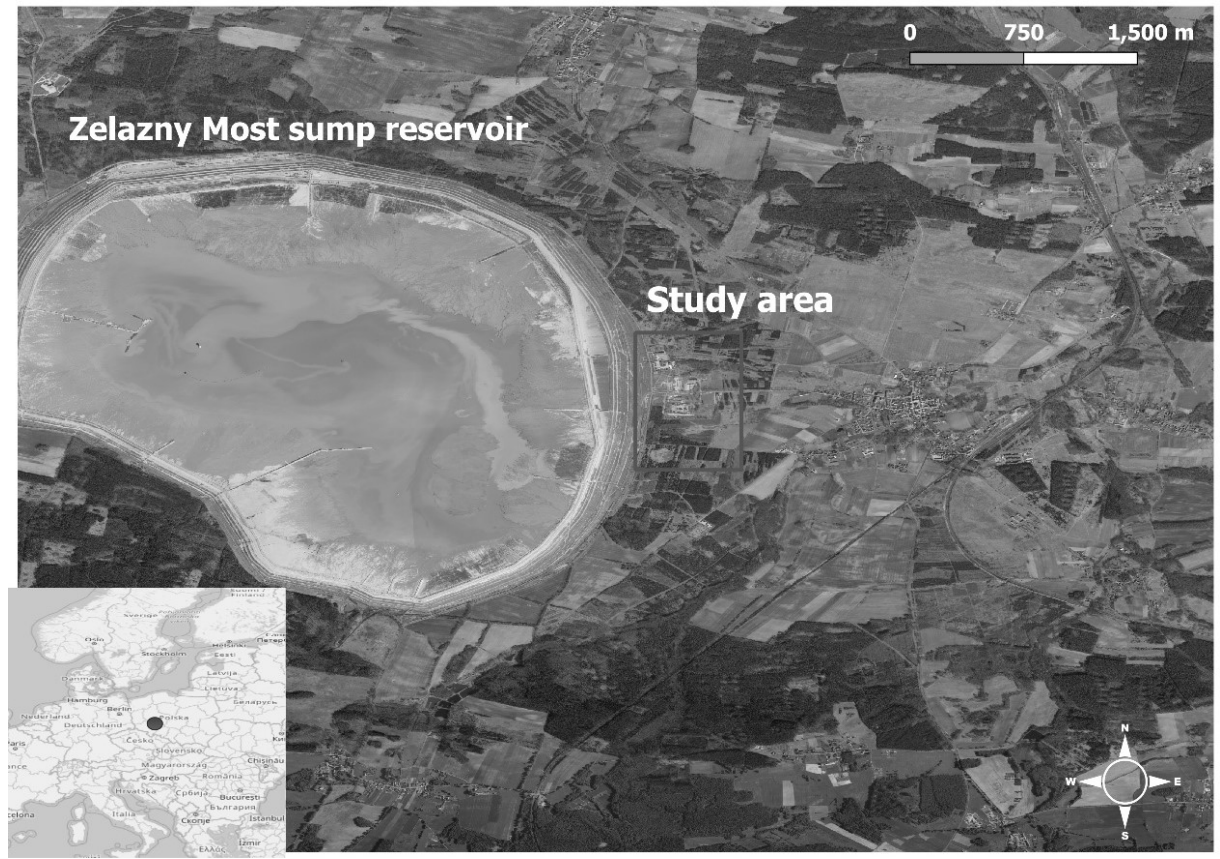

Fig. 1 Location of Żelazny Most dump and the study area 
Flotation tailings have a form of pulp with average density of about 180-200 g/l. They are transported and discharged by pipes which outlets are situated along the embankments. Each of the outlet forms a discharge zone with a length of about $500[\mathrm{~m}]$. Thereby the coarsest fractions are placed in the outer part of the dam and central part is composed of the finest fractions of tailings. Additionally, in the centre of the dump there is a pond of about 10 million $\mathrm{m}^{3}$ of industrial water, which contains about $15.000-20.000 \mathrm{mg} / \mathrm{l}$ of total dissolved solids. Major substances dissolved in water stored in Żelazny Most dump are chlorides, sulphates and sodium which concentrations in 2000 were respectively: 8800 $\mathrm{mg} / \mathrm{l}, 2900 \mathrm{mg} / \mathrm{l}$, and $5500 \mathrm{mg} / \mathrm{l}$ (Czaban and Górski, 1995). Water contains also other hazardous substances like phenols, detergents, cyanides, xanthates and heavy metals. Whence, water migrating to groundwater and toward reservoir foreground, poses a serious ecological threat (Lasocki et al., 2003). To prevent this, system of dewatering ditches and wells of vertical drainage was built around the dump. Ditches are located along the embankments and well are located on the foreground of the dump. Water collected by ditches and well is pumped away and used in hydrotransport of flotation tailings. More information about dewatering system could be found in (Duda et al., 2003). The most exposed to infiltration of industrial water is eastern foreground, because of the lack of natural barriers like hill ranges.

Monitoring system consists of wells and piezometers placed on the foreground of the dump. Groundwater samples are taken from wells and used to determine concentrations of hazardous substances dissolved in groundwater. Measurement results could be utilised to obtain spatial distribution of harmful substances concentrations in groundwater. Previous studies carried on up to the present confirm the fact of water migration from dump toward foreground. In those studies, spatial distributions of different kind of contaminants were obtained mostly using kriging and indicator kriging (Zawadzki J., et al., 2004).

The idea of this study was to integrate information provided by chemical analyses and geoelectrical measurements, utilizing correlation between electrical resistance of the soil solution and total dissolved solids concentration in groundwater (Vaughan et al., 1995). Data integration was done using cokriging method. Hence, it was possible to obtain spatial distribution of total dissolved solids concentrations in groundwater at the eastern part of Żelazny Most dump foreground.

\section{METHODOLOGY OF RESEARCH}

The study area was a part of the eastern foreground of Żelazny Most dump, placed between dam and Rudna, the biggest town placed in the vicinity. Study area was square-shaped with dimensions of about 1046 and $695 \mathrm{~m}$ and area of about $0.7 \mathrm{~km}^{2}$. At the studied part of the foreground 33 wells were placed in irregular way. Additionally, on the study area series of 73 geoelectrical measurements were carried out. Measuring net was also irregular. Average 
distance between wells and geoelectrical measurement points was about 120 $\mathrm{m}$ and $60 \mathrm{~m}$, respectively.

Groundwater samples for chemical analyses were taken from wells placed on the foreground of the reservoir. Then, water samples were vaporized in a quartz pot on a water bath to dry and calcined in a stove in temperature of $550-600^{\circ} \mathrm{C}$. Dry remainder was used to determine the concentration of total dissolved solids, chlorides, sulphates and sodium in groundwater. In this study concentration of total dissolved solids was chosen to be used in cokriging method as primary variate. This indicator depends on other indicators, like chlorides, sulphates and sodium, which are more detailed indicators. Furthermore, in comparison with other indicators, concentration of total dissolved solids revealed stronger correlation with electric resistance of ground. Pearson's correlation coefficient was equal around -0.65 . This fact is advantageous in cokriging method. Its negative value results from the fact that increase of total dissolved solids concentrations in groundwater causes decrease of electrical resistance of ground.

Application of cokriging requires secondary variate to be supplied, which in this study was electric resistance of ground. The general rule of the geoelectrical measurement technique is to produce an electrical field in ground using two electrodes supplied by direct current and to measure simultaneously created potential difference, as a result of current flow through the ground (Lesch, 1995; Antoniuk, 2002; Mościcki and Antoniuk, 2002; Reedy and Scanlon, 2003). The way of probing is to place electrodes $A, B$ on one line in relation to the point $O$, co-called the centre of probing (Fig. 2) and then to gauge the electric resistance with electrodes $\mathrm{M}, \mathrm{N}$. Depth of penetration in soil profile depends linear on the distance between electrodes A, B and increase along with the span. In this case distance between electrodes was $32 \mathrm{~m}$. This method is sometimes called vertical probing. Measurements results were expressed in ohmmeters $(\Omega \mathrm{m})$.

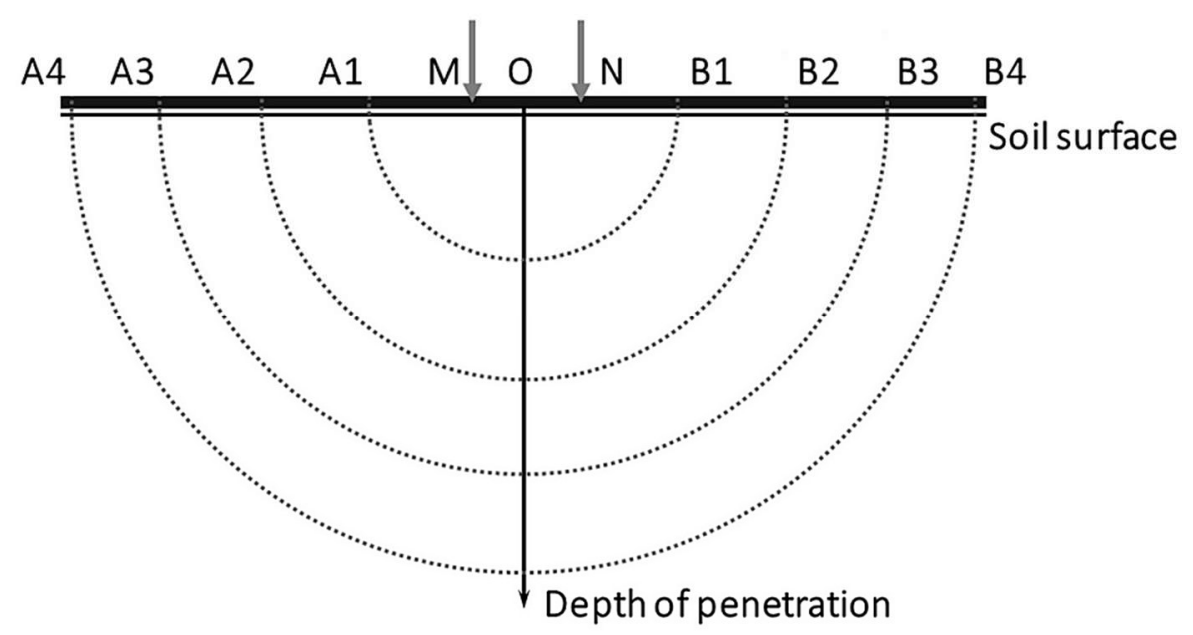

Fig. 2 Scheme of measurement technique of electric resistance of ground 
Available data set consists of 33 measurements of total dissolved solids concentration in groundwater and 73 measurements of electric resistance of the ground.

Cokriging is variety of kriging and that allows one to use multiple variates, which must be strongly correlated with each other (Isaaks et al., 1989; Zawadzki J. 2003). Cokriging finds application in situation when samples of primary variate are difficult to collect, too expensive or too rarely sampled. Likewise, kriging, cokriging minimizes variance of estimation error of primary variate, utilizing cross-correlations between primary variate and secondary variates (Journel and Huibregts, 1978; Han, 2003; Fabijańczyk and Sobiech, 2003; NamysłowskaWilczyńska, 2006; Zawadzki, 2011). Value of primary variate $\hat{u}_{0}\left(x_{0}\right)$, estimated at unknown location is calculated using linear combination of both variates and comes as follows:

$$
\hat{u}_{0}\left(x_{0}\right)=\sum_{i=1}^{n} a_{i}\left(x_{i}\right) \cdot u_{i}\left(x_{i}\right)+\sum_{j=1}^{m} b_{j}\left(x_{i}\right) \cdot v_{j}\left(x_{j}\right)
$$

where:

$u_{i}, v_{i}-$ primary and secondary data values at i-th location

$a_{i}, b_{i}$ - cokriging weights

The estimation error is given by expression:

$$
R(x)=\hat{u}_{0}(x)-u_{0}(x)=\sum_{i=1}^{n} a_{i}\left(x_{i}\right) \cdot u_{i}(x)+\sum_{j=1}^{m} b_{j}\left(x_{i}\right) \cdot v_{j}(x)-u_{0}(x)
$$

where:

$u_{0}(x)$ is an actual value.

Weights set $a_{i}\left(x_{i}\right), b_{j}\left(x_{i}\right)$ must be utilized in order to make estimation unbiased and to minimize variance of estimation error.

The unbiased condition is true when weights are utilized as follows:

$$
\begin{aligned}
& \sum_{i=1}^{n} a_{i}\left(x_{i}\right)=1 \\
& \sum_{j=1}^{m} b_{j}\left(x_{i}\right)=0
\end{aligned}
$$

Cokriging can be used when semivariogram models for primary, secondary variate and cross-semivariogram are known:

$$
\left\{\begin{array}{l}
\gamma_{u}(h)=u_{0} \gamma_{0}(h)+u_{1} \gamma_{1}(h)+\ldots+u_{k} \gamma_{k}(h) \\
\gamma_{v}(h)=u_{0} \gamma_{0}(h)+u_{1} \gamma_{1}(h)+\ldots+u_{k} \gamma_{k}(h) \\
\gamma_{u v}(h)=u_{0} \gamma_{0}(h)+u_{1} \gamma_{1}(h)+\ldots+u_{k} \gamma_{k}(h)
\end{array}\right.
$$

where:

$Y u, \gamma_{v}, \gamma_{u v}$ - semivariogram model for primary, secondary variate and crosssemivariogram respectively

$h$-distance between two points (one pair) used to calculate semivariogram. 
These equations must be positively determined, which also is known as linear model of coregionalization. This condition is true when the fallowing equations are true:

$$
\begin{aligned}
& u_{i}>0 \wedge v_{i}>0 \\
& u_{i} \cdot v_{i}>w_{i} \cdot w_{i}
\end{aligned}
$$

Cokriging is an effective method of estimation that allows one to make use of additional information about studied phenomena. This could be quantitative as well as qualitative information. It makes it possible to integrate different types of information like chemical, physical and geological to obtain more precise spatial distribution of analysed indicator. Cokriging is useful when primary measurements are expensive, time-consuming or data set is too sparse. Then it is possible to replenish primary variate with less expensive and easy-tomeasure additional measurements.

\section{RESULTS AND DISCUSSION}

In the very begging descriptive statistics, which are listed in Table 1, were computed for concentrations of total dissolved solids and electric resistance of ground. It is visible that distributions of both chemical and geophysical measurements are characterized by significant positive skewness.

Table 1 Descriptive statistics of total dissolved solids concentrations

\begin{tabular}{|l|c|c|}
\hline & $\begin{array}{c}\text { Total dissolved } \\
\text { solids concentration }\end{array}$ & $\begin{array}{c}\text { Electric resistance } \\
\text { of ground }\end{array}$ \\
\hline Number & 33 & 73 \\
\hline Average & $3218.4[\mathrm{mg} / \mathrm{l}]$ & $50.8[\Omega \mathrm{m}]$ \\
\hline Median & $1040.0[\mathrm{mg} / \mathrm{l}]$ & $44.0[\Omega \mathrm{m}]$ \\
\hline Mode & $276.0[\mathrm{mg} / \mathrm{l}]$ & $34.0[\Omega \mathrm{m}]$ \\
\hline Lower quartile & $310.0[\mathrm{mg} / \mathrm{l}]$ & $34.0[\Omega \mathrm{m}]$ \\
\hline Upper quartile & $5360.0[\mathrm{mg} / \mathrm{l}]$ & $60.0[\Omega \mathrm{m}]$ \\
\hline Minimum & $102.0[\mathrm{mg} / \mathrm{l}]$ & $17.5[\Omega \mathrm{m}]$ \\
\hline Maximum & $18732.0[\mathrm{mg} / \mathrm{l}]$ & $240.0[\Omega \mathrm{m}]$ \\
\hline Range & $18630.0[\mathrm{mg} / \mathrm{l}]$ & $222.5[\Omega \mathrm{m}]$ \\
\hline Variance & $2.230 \cdot 107\left[(\mathrm{mg} / /)^{2}\right]$ & $943.8\left[(\Omega \mathrm{m})^{2}\right]$ \\
\hline Standard deviation & $358.18[\mathrm{mg} / \mathrm{l}]$ & $3.75[\Omega \mathrm{m}]$ \\
\hline Skewness & 1.47 & 3.79 \\
\hline
\end{tabular}

Table 2 presents maximum allowable concentrations of total dissolved solids in sewage discharged into the ground or water and maximum allowable concentration for water cleanliness of class III (according to polish norms). Measured concentrations of total dissolved solids in groundwater were significantly higher than those listed in 
Table 2 Maximum allowable concentrations of total dissolved solids in sewage discharged into the ground or water and maximum allowable concentration for water cleanliness of class III

\begin{tabular}{|l|c|}
\hline class I & $<500[\mathrm{mg} / \mathrm{l}]$ \\
\hline class II & $<1000[\mathrm{mg} / \mathrm{l}]$ \\
\hline class III & $<1200[\mathrm{mg} / \mathrm{l}]$ \\
\hline $\begin{array}{l}\text { Maximum allowable concentration of total } \\
\text { dissolved solids in sewage discharged into } \\
\text { the ground or water }\end{array}$ & $<2000[\mathrm{mg} / \mathrm{l}]$ \\
\hline
\end{tabular}

The next step of the study was computation of semivariograms for both measured indicators. Isotropic semivariograms were modelled using two structures: nugget effect and spherical model. Cross-semivariogram and its model were computed in the same way. The modelling of a semivariogram and cross-semivariogram is an important step in each geostatistical analysis (Gringarten and Clayton, 2001; Zawadzki and Fabijańczyk, 2013). Parameters of all models are listed in Table 3. Semivariogram and cross-semivariogram models were used to create linear model of coregionalization, which is a necessary step in cokriging method.

Table 3 Parameters of semivariogram and cross-semivariogram models;

$Y u, Y v, Y u v$ denotes primary, secondary variate and cross-semivariogram respectively

\begin{tabular}{|l|c|c|c|}
\hline & $Y u$ & $Y_{v}$ & $Y u v$ \\
\hline Nugget effect & $55 \cdot 104\left[(\mathrm{mg} / /)^{2}\right]$ & $16.2[\Omega \mathrm{m}]$ & -10.0 \\
\hline Model type & Spherical & Spherical & Spherical \\
\hline Sill & $1026 \cdot 104\left[(\mathrm{mg} / /)^{2}\right]$ & $187.8[\Omega \mathrm{m}]$ & -8620.0 \\
\hline Range & $262[\mathrm{~m}]$ & $852[\mathrm{~m}]$ & $425.6[\mathrm{~m}]$ \\
\hline
\end{tabular}

Ranges of semivariogram models indicated that the spatial continuity of electric resistance was higher than in case of total dissolved solids concentrations.
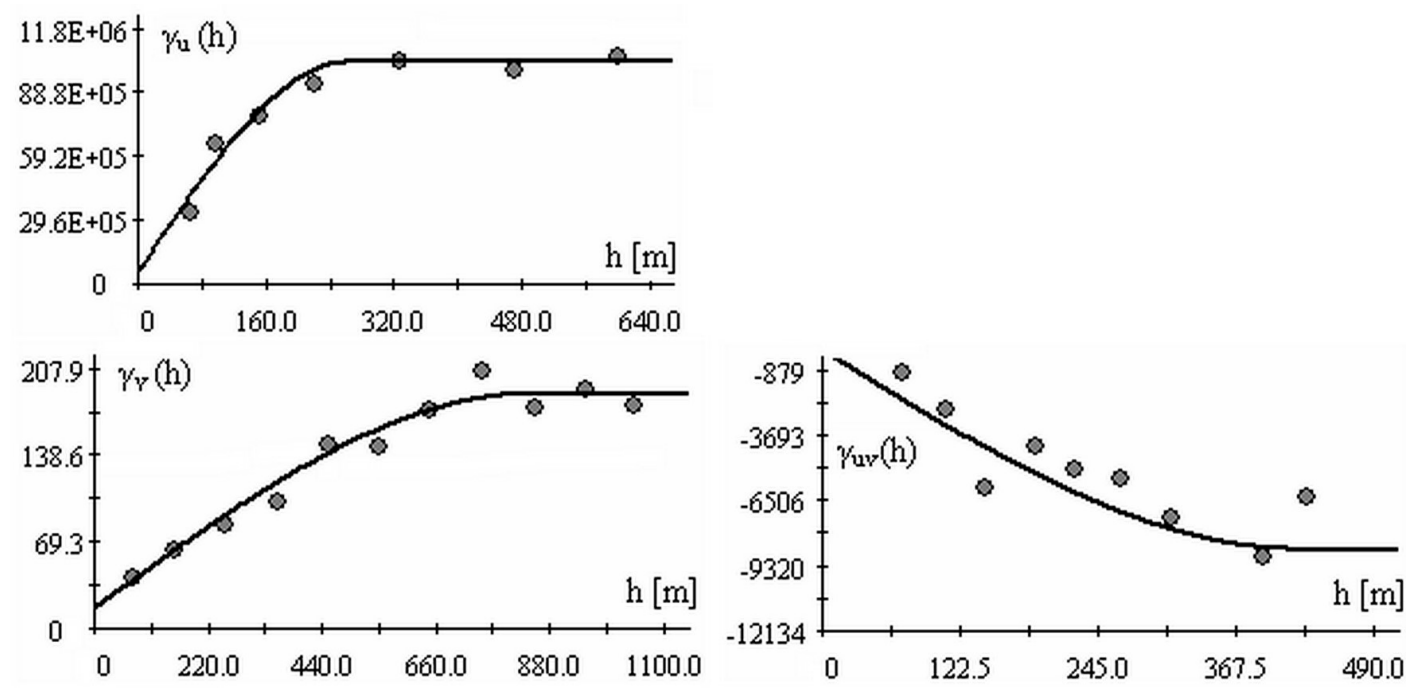

Fig. 3 Experimental semivariograms and semivariance models for concentrations of total dissolved solids and electric resistance of the ground 
Correlations range for electric resistance and total dissolved solid concentrations equalled $852 \mathrm{~m}$ and $262 \mathrm{~m}$, respectively.

The following step was computation of spatial distribution of total dissolved solids concentrations in groundwater. To create possibility of comparison three estimation methods were used: inverse distance weighting, kriging and cokriging. To increase the legibility of maps each threshold of total dissolved solid concentration, had length of $1200 \mathrm{mg} / \mathrm{l}$. This equals the maximum allowable concentration for water cleanliness of class III (see also Table 2). Hence each of thresholds denotes how many times the maximum allowable concentration for water cleanliness was exceeded.

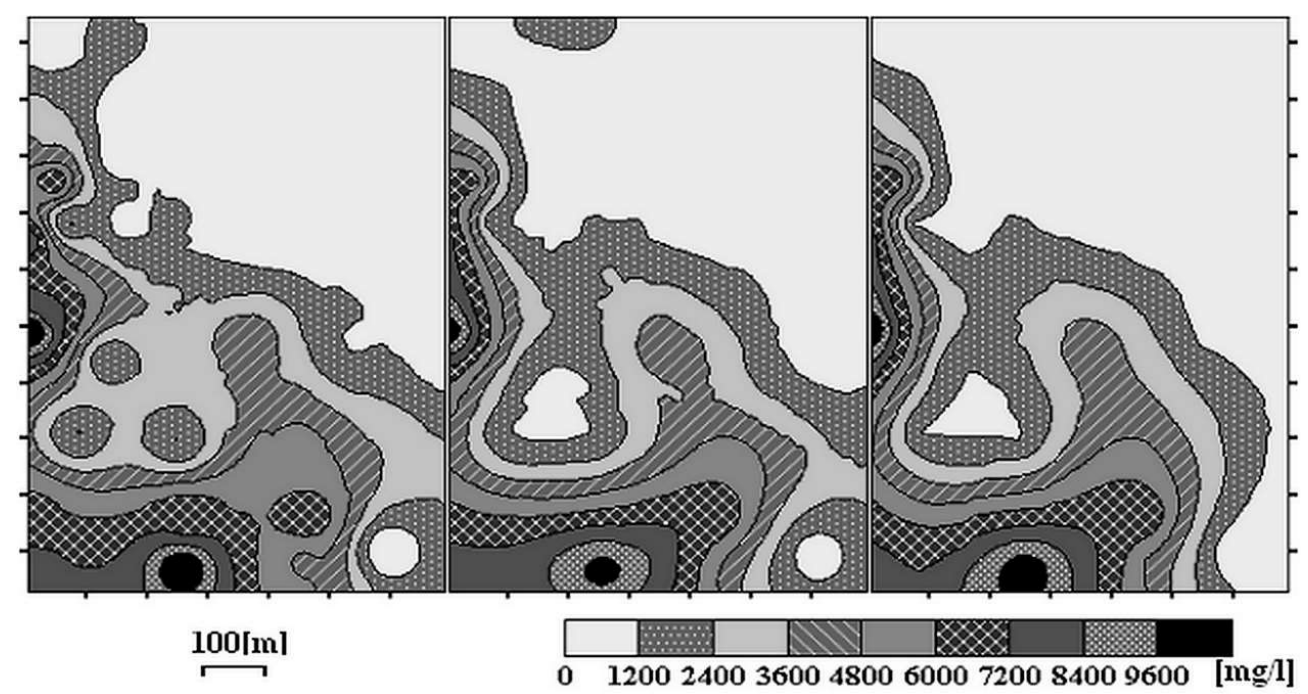

Fig. 4 Maps of spatial distribution of total dissolved concentrations in groundwater at the part of eastern foreground of Żelazny Most dump; wells were denoted by black circle and geoelectrical measurement points were denoted by grey cross; values expressed in $[\mathrm{mg} / \mathrm{l}]$

In case of kriging and cokriging standard deviations maps were calculated. The influence of additional information brought by measurements of electric resistance led to decrease of estimation uncertainty in cokriging method. Therefore, average decrease of standard deviations values for total dissolved solid concentrations was about $25 \%$.

Additionally, for each estimation method cross-validation analysis was performed. Each measuring point was individually removed from domain and total solids concentration was estimated at this point. In the next step measured concentration was compared with estimated one and the whole process was repeated until it covered all measuring points. Then Pearson correlation coefficient between estimated and measured concentrations was calculated. The results of cross-validation are presented in Table 4. 


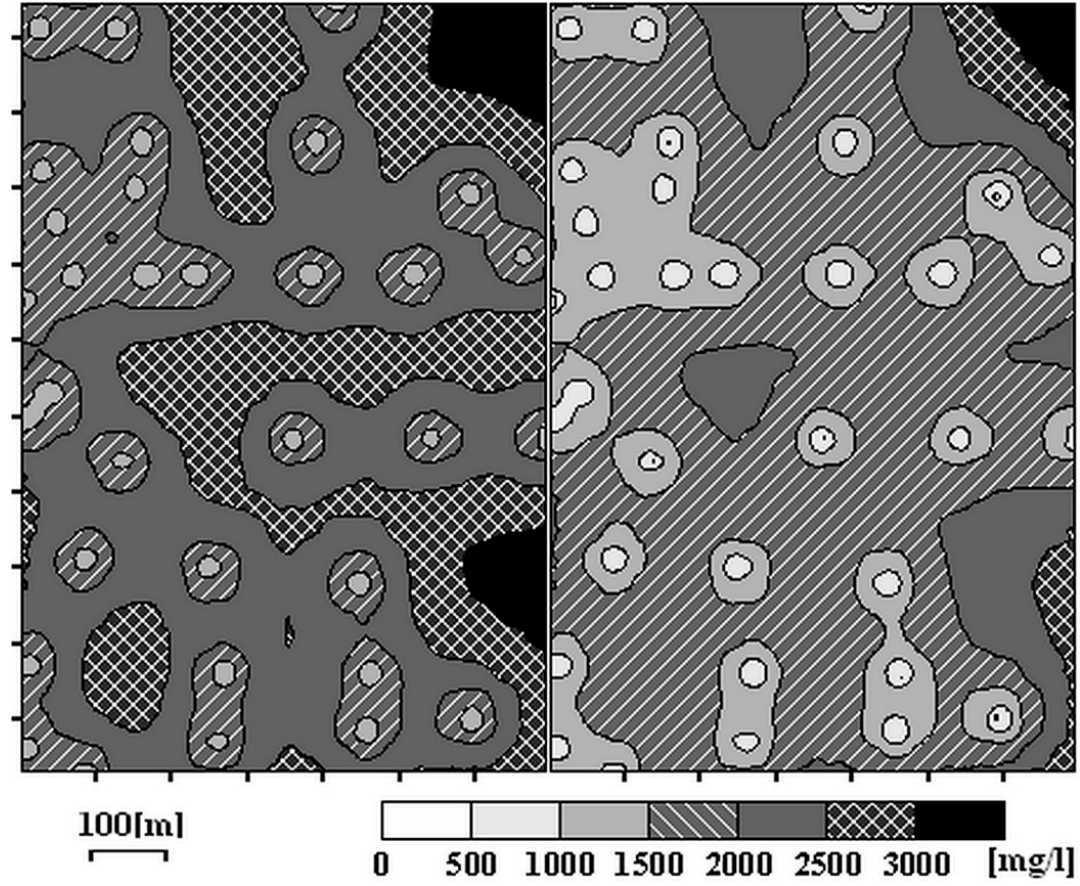

Fig. 5 Standard deviations maps; left for kriging and right for cokriging; values expressed in $\mathrm{mg} / \mathrm{l}$

Table 4 Results of the cross-validation analysis

\begin{tabular}{|l|c|c|c|}
\hline & IDW & Kriging & Cokriging \\
\hline $\begin{array}{l}\text { Correlation coefficient between estimated } \\
\text { and measured values }\end{array}$ & 0.673 & 0.747 & 0.773 \\
\hline Regression coefficient & 0.970 & 1.071 & 0.976 \\
\hline Standard error of regression coefficient & 0.191 & 0.171 & 0.144 \\
\hline
\end{tabular}

On the grounds of cross-validation results the advantage of cokriging and kriging over IDW method can be noticed. In case of cokriging method the improvement of estimation results was also observed.

\section{CONCLUSION}

The study results indicated that it is possible to effectively use measurements of electrical resistance of the ground to complete chemical analyses of groundwater samples. It was noticeable not only in cross-validation but also in the standard deviation maps. In addition, the analysis of semivariances and cross-semivariances made it possible to obtain information about the spatial auto-correlation of both types of measurements, and the cross-correlation between different measurements. Such information makes it possible to better assess the effectiveness and mutual matching of the applied measurement methods. Although kriging methods are used in Poland, their applications are still not routine ones, like other methods of classical regression. The advantage of the cokriging method, which deserves special emphasis, is the possibility of integrating multi-sources spatial data. As a result, the precision of estimates 
increases, especially in the case of insufficiently numerous measurements, and the measurement costs are significantly reduced.

\section{REFERENCES}

Antoniuk J., (2002). Geoelectrical monitoring of chemical pollution of underground, Geophysical research of geological environment (Publications of the Institute of Geophysics Polish Academy of Sciences), M-27, pp. 167-178.

Czaban S., Górski R., (1995). Water and waste products balance of "Żelazny Most" reservoir, in: VII Konferencja Sozologiczna, May 1995, Polkowice.

Duda R., Witczak S., (2003). Modeling of the transport of contaminants from the Żelazny Most flotation tailings dam, Gospodarka Odpadami Mineralnymi, 19(4), pp. 69-87.

Gringarten E., Clayton V., (2001). Deutsch Teacher's Aide Variogram Interpretation and Modeling, Mathematical Geology, 33(4), pp. 507-534.

Fabijańczyk P., Sobiech, M. (2003). Znaczenie kokrigingu w inżynierii środowiska na przykładzie badań rozkładu zanieczyszczeń na fragmencie przedpola wschodniego zbiornika osadów poflotacyjnych „Żelazny Most”. MSc Thesis (in Polish), Warsaw University of Technology.

Han S., Schneider M., Evans G., (2003). Evaluating cokriging for improving soil nutrient sampling efficiency, Transactions of the ASAE, 46(3), pp. 845-849.

Isaaks E., H., R. Srivastava M. (1989). Applied Geostatistics, Oxford University, New York.

Jamiolkowski, M. (2014). Soil mechanics and the observational method: Challenges at the Zelazny Most copper tailings disposal facility, Géotechnique, 64(8), pp. 590618.

Journel A.G., Huibregts C.J. (1978). Mining Geostatistics, Academic Press, London.

Lasocki S., Antoniuk J., Mościcki J. (2003). Environmental protection problems in the vicinity of the Żelazny Most flotation wastes depository in Poland, Journal of Environmental Science and Health, A38(8), pp. 1435-1443.

Lesch M.S., Strauss D.J., Rhoades J.D. (1995). Spatial prediction of soil salinity using electromagnetic induction techniques, Water Resources Research, 31(2), pp. 373-386.

Mościcki J., Antoniuk J. (2002). Application of geoelectric methods into studying of geological environment influenced by human activity, Geophysical research of geological environment (Publications of the Institute of Geophysics Polish Academy of Sciences), M-27, pp. 179-193.

Reedy R.C., Scanlon B.R. (2003). Soil water monitoring using electromagnetic induction, Journal of Geotechnical and Geoenvironmental Engineering, 129(11), pp. 1028-1039.

Vaughan P.J., Lesch M.S., Corwin D.L., Cone D.G. (1995). Water content effect on soil salinity prediction: a geostatistical study using cokriging, Soil Science Society of America Journal, 59(4), pp. 1146-1156.

Namysłowska-Wilczyńska B. (2006). Geostatystyka: teoria i zastosowania. Wrocław: Oficyna Wydawnicza Politechniki Wrocławskiej.

Skau, K., Andresen, L., Jostad, P., Fornes, P., Grimstad, G., Page, A. (2013). Stability and deformations of Zelazny Most dam - One of the World's largest deponies for copper tailings. In Fjellsprengningsdagen, Bergmekanikkdagen, Geoteknikkdagen.

Zawadzki J., Kucharek M., Treichel W. (2004). The modeling of spatial distribution of chlorine ion concentration in groundwater from post-flotation reservoir „Żelazny Most", Engineering \& Protection of Environment, 7(3-4), pp. 381-392.

Zawadzki J. (2003). Introduction to integration of spatial data by cokriging method, Wiadomości Statystyczne GUS, 5, pp. 7-21. 
Zawadzki J. (2011). Metody geostatystyczne dla kierunków przyrodniczych i technicznych. Warszawa: Oficyna Wydawnicza Politechniki Warszawskiej.

Zawadzki J., Fabijańczyk P. (2013). Geostatistical evaluation of lead and zinc concentration in soils of an old mining area with complex land management, International Journal of Environmental Science and Technology, 10 (4), pp. 729742.

\begin{abstract}
The study presents the possibility of using geostatistical methods for monitoring groundwater quality. Poland is one of the largest copper producers in the world. However, the extraction and production of copper requires constant care for the natural environment. Reservoir Żelazny Most which is situated in South Western Poland was designed to store flotation tailings out of nearby copper mines. It is one of the biggest industrial dumps in the world. The reservoir stores huge amounts of tailings and industrial water. Water migrating from dump to groundwater could be a potential source of contamination with chlorides, sulphates, heavy metals, and other hazardous substances used in ore separation process in the copper mining industry, like detergent and phenols. Monitoring system around Żelazny Most dump, which was designed to track harmful substances concentrations in groundwater, contains measuring wells and piezometers. They are used to collect groundwater samples for chemical analyses. The idea of the study was to integrate information provided by chemical analyses and geoelectrical measurements by cokriging method, utilizing correlation between electrical resistance of the soil solution and total dissolved solids concentration in groundwater. This enabled to obtain spatial distribution of total dissolved solids concentrations in groundwater at the part of eastern foreground of Żelazny Most dump.
\end{abstract}

Keywords: cokriging, geoelectrical measurements, geostatistics, total dissolved solids, Żelazny Most dump 